\title{
INVESTIGATING THE BARRIERS TO LASER SCANNING IMPLEMENTATION IN BUILDING REFURBISHMENT
}

\author{
SUBMITTED: January 2021
}

REVISED: April 2021

PUBLISHED: May 2021

EDITOR: Robert Amor

DOI: $10.36680 /$ j.itcon.2021.014

\author{
Ulrika Uotila, Doctoral Researcher \\ Tampere University \\ ulrika.uotila@tuni.fi

\section{Arto Saari, Professor \\ Tampere University \\ arto.saari@tuni.fi}

Juha-Matti Junnonen, Lic. Sc. (Tech)

Tampere University

juha-matti.junnonen@tuni.fi

\begin{abstract}
SUMMARY: The use of the laser scanning technique has increased rapidly in the field of built environment, mainly because it produces highly accurate as-built data. However, the full potential of this technique is utilised only limitedly in building refurbishment projects. This research aims to investigate the barriers to the implementation of laser scanning in building refurbishment projects in Finland. Qualitative interviews were carried out to identify these barriers, and furthermore, to explore the current usage of the technique in building refurbishments. The study shows that many obstacles to implementations are related to challenges in laser scanning procurement, including a low level of competence in acquisition, limitations of the laser scanning technique in building refurbishments, and limitations and challenges in utilising the data in design work. This study is beneficial for building owners and practitioners as it presents the challenges and advantages that laser scanning can provide a refurbishment project. In addition, it offers suggestions to improve the early phase of a refurbishment project in order to achieve greater benefits with laser scanning. Furthermore, the findings may be utilised in the procurement process of laser scanning services in such projects, and the results may potentially solve practical challenges encountered in laser scanning work.
\end{abstract}

KEYWORDS: laser scanning, building refurbishment, refurbishment project, as-built, 3D data, project management, refurbishment management.

REFERENCE: Ulrika Uotila, Arto Saari, Juha-Matti Junnonen (2021). Investigating the barriers to laser scanning implementation in building refurbishment. Journal of Information Technology in Construction (ITcon), Vol. 26, pg. 249-262, DOI: 10.36680/j.itcon.2021.014

COPYRIGHT: (C) 2021 The author(s). This is an open access article distributed under the terms of the Creative Commons Attribution 4.0 International (https://creativecommons.org/licenses/by/4.0/), which permits unrestricted use, distribution, and reproduction in any medium, provided the original work is properly cited. 


\section{INTRODUCTION}

The management of a building refurbishment project is, typically, challenging, as the project is influenced by unforeseen elements and changing factors (Arain, 2005). These variables generate a high level of uncertainty and multiple technical and economic risks to the project (Noori et al., 2016; Oloke, 2017; Rahmat and Ali, 2010; Zolkafli et al., 2012). Many of these risks are connected to deficient as-built data of the existing building, including incorrect measurements and deficient structural details (Oloke, 2017; Uotila et al., 2020b, 2020a; Zolkafli et al., 2012). These defects of as-built data increase project costs, cause errors in design and construction work, and even extend the project time (Love and Edwards, 2004; McKim et al., 2000; Naaranoja and Uden, 2007). A majority of these negative consequences could potentially be diminished by using more accurate as-built data of the existing building.

Fatal decisions with the most detrimental consequences are made during the early phase of a refurbishment project. In particular, faults and decisions made in the design phase can have a substantial influence on costs, project times and the quality of the entire project (Chua et al., 2003). Also, uncertain conditions of existing buildings result in limitations in the design phase, which significantly hinder the designer's ability to complete the design task before work starts at the site (Ali et al., 2008). These design faults can be reduced, and the overall design phase streamlined, with improved initial data management of existing buildings (Cepurnaite et al., 2017). Moreover, better management of the initial data can produce more reliable information for further stages of the building life cycle (Cepurnaite et al., 2017). Thus, accurate as-built data, as well as proper information about the structures of the existing building, are essential for the success of a building refurbishment project.

Laser scanning (LS) has become a common and beneficial tool for the gathering of spatial data of existing buildings. It is used particularly for creating as-built BIM models. Fast and accurate data acquisition, including millions of measurement points of the existing building, is the feature why LS is preferred over conventional methods. In building refurbishment projects, the LS technique is also used for identifying deviations from design, real time monitoring (Brilakis et al., 2010), quantity estimates, and quality control (Akinci et al., 2006; Tang et al., 2011; Wang, Sun, et al., 2015).

Despite the great potential of LS, understanding of the utilisation of the technique in building refurbishment projects is still deficient in the field. The defects and challenges related to the adoption of laser scanning in data capturing of existing buildings are widely established by case studies. However, since these studies focus primarily on technical aspects and concern LS work and as-built creation in particular projects, these findings do not explain how these challenges effect the procurement of LS services. This motivates investigations regarding the barriers to LS implementation in building refurbishment projects in Finland. The study explores the topic by focusing on the viewpoints of clients and other project parties.

\section{DATA CAPTURING IN BUILDING REFURBISHMENT PROJECTS}

Knowledge of positions, geometries, sizes, shapes, and components of an existing building is needed as a starting point of building refurbishment. This information provides a framework for design, further construction analysis, and as-built modelling. Currently, multiple methods are used for capturing the spatial data of an existing building in a building refurbishment project. The choice of the survey technique relies, typically, on the intended use of the data and the need for data accuracy. But, the choice depends, also, on the complexity and size of the building, the budget, the required expertise of applications, and the equipment available (Historic England, 2018). Often, multiple parallel techniques are used to get more accurate spatial data of existing buildings (Historic England, 2018).

Since traditional manual methods, such as manual laser distance measurements, flexometers and calipers, are simple to use, they are, typically, suitable for capturing certain measures and locations, but impractical for large and complex structures (Historic England, 2018) and inefficient in gathering data for 3D models (Göçer et al., 2016; Liu and Kang, 2014). Topographic methods, such as tacheometers and theodolites, are accurate but timeconsuming in the field and producing the data into a 3D model is complex. A total station is usually used for recording precise measurements and georeferencing (Lachat et al., 2017; Murtiyoso and Grussenmeyer, 2018; Sun and Cao, 2015). A global navigation satellite system (GNSS) is mainly used for geographic information system data collection and topographic work (Historic England, 2018). 
The data acquisition methods for 3D data of existing buildings may be divided into two categories: the photogrammetrical techniques and the LS techniques (Historic England, 2018). As it is possible to collect millions of points quickly with these techniques, they are appropriate methods to use especially in more complex and largersized building refurbishments. This data can be used on several platforms for various purposes. Often, this accurate spatial data of an existing building is used for the creation of an as-built Building Information Model (as-built BIM), which, typically, refers to the representation of an existing building at the moment of the survey (Hichri et al., 2013; Tang et al., 2010). Even though BIM adaptation of existing buildings is still not as common as BIM implementation in new building projects, the use of BIM applications in refurbishment planning, as-built documentation, construction inspection, facility management and maintenance has increased recently (Nguyen and Choi, 2018; Volk et al., 2014; Wang, Cho, et al., 2015). As the creation of a BIM model for an existing building is known as an as-built BIM (Tang et al., 2010), an HBIM refers to the as-built BIM of a heritage or historical building. An HBIM is based on a scan-to-BIM process that enables the generation of a 3D model from laser scan or photogrammetric survey data (Aicardi et al., 2018; Allegra et al., 2020; Capone and Lanzara, 2019; Dore and Murphy, 2012; Ebolese et al., 2018). Contrary to an as-built BIM, an HBIM offers solutions for the parametric modelling of historic buildings and structures, as it includes a library of historic architectural objects for BIM software platforms (Aicardi et al., 2018; Cheng et al., 2015).

\subsection{Photogrammetry}

Photogrammetric techniques rely on images taken from different viewpoints to record the 3D geometry of a building or objects (Dore and Murphy, 2017). As these techniques are quick and easy to use, and the costs of devices are relatively low (Altman et al., 2017; Brilakis et al., 2010; Dobelis et al., 2016; Ulvi, 2021; Yang et al., 2020), the recording of existing buildings by photogrammetry has increased recently (Dore and Murphy, 2017; Yang et al., 2020). Even though photogrammetry has several advantages compared to laser scanning, including high-quality imagery and colour information (Dore and Murphy, 2017), there are also multiple challenges related to this technique. The main difficulties include a time-consuming computational data process (Dore and Murphy, 2017; Fassi et al., 2013; Ulvi, 2021), less accurate and dense point clouds than a laser scanner can provide (Altman et al., 2017; Golparvar-Fard et al., 2011; Lee et al., 2015; Mellado et al., 2020; Ulvi, 2021), and the requirement of proper lighting (Rocha et al., 2020). For overriding the challenge of a laborious data process, photogrammetric techniques are evolving towards automatic post processing (Aicardi et al., 2018; Dore and Murphy, 2017). However, the quality and accuracy of the results produced by these automatic techniques do not, yet, reach the level of manual or semi-manual procedures (Gruen, 2012).

\subsection{Laser Scanning}

Currently, terrestrial LS is one of the most common methods for gathering as-built data of existing buildings (Becker et al., 2019; Dore and Murphy, 2017; Suchocki, 2020) due to the high accuracy and point density that the technique provides (Abdul Shukor et al., 2015; Alomari et al., 2016; Cheng et al., 2015; Han, 2012; Hong et al., 2015; Lee et al., 2015; Sepasgozar et al., 2015; Shanbari et al., 2016; Volk et al., 2014). A terrestrial laser scanner captures the geometry and textual information of an existing building by automatically recording millions of 3D points (Dore and Murphy, 2017; Rocha et al., 2020). Laser scanners mainly use one of three different principles for measurements: triangulation, time-of-flight (ToF), or phase-comparison. Even though all of these methods produce a 3D point cloud, the range and accuracy of registered values vary between these methods (Dore and Murphy, 2017; Historic England, 2018; Suchocki, 2020). Typically, laser scanners operated by ToF or phase are used in the recording of building exteriors and interiors (Historic England, 2018).

The laser scanning technique has evolved rapidly in recent years. This progress has resulted in a launch of more compact platforms, including mobile, handheld, backpack and trolley LS devices (Chen et al., 2019; Otero et al., 2020). In particular, the handheld and backpack devices are suitable for indoor surveying due to their light weight and small size (Chen et al., 2019; Otero et al., 2020). These equipment are more efficient in use but provide a less dense and noisier point cloud than terrestrial LS (Kukko and Kaartinen, 2019; Lehtola et al., 2017; Otero et al., 2020; Previtali et al., 2019). However, the operating time of these devises is rather similar to a terrestrial laser scanner, and these methods are suitable for data acquisition of buildings where accurate data is not required (Otero et al., 2020; Previtali et al., 2019). Even though these novel LS methods may offer multiple benefits in as-built data capturing of existing buildings, they are still not as common in data acquisition of existing buildings as the traditional terrestrial laser scanner (Kukko and Kaartinen, 2019). 
Multiple studies present LS as overriding the other data gathering techniques in shorter survey duration (Le et al., 2018; Sanhudo et al., 2018; Ustinovichius et al., 2018), improved accuracy (Sanhudo et al., 2018), the possibility for an automated generation of BIM models (Bassier et al., 2018; Gimenez et al., 2015), and its possibility to capture complex shape geometries (Amano et al., 2019; Sanhudo et al., 2018, 2020). Despite the still increasing advantages due to the evolving LS technique, LS has several limitations. These downsides include required expertise (Sanhudo et al., 2018; Shanbari et al., 2016; Volk et al., 2014), laborious further processes (Allegra et al., 2020; Historic England, 2018; Sanhudo et al., 2018, 2020; Tang et al., 2010; Tkáč et al., 2018; Xiong et al., 2013), and expensive equipment (Alomari et al., 2016; Altman et al., 2017; López et al., 2018; Sanhudo et al., 2020; Volk et al., 2014). In addition, laser scanners are not as flexible as cameras with regard to acquiring data (Historic England, 2018). However, the rapidly improving laser technology, such as more compact devices, may decrease these downsides concerning device costs and expertise.

As BIM models require accurate spatial information of building parameters, laser scanning is commonly adopted to collect this data (Badenko et al., 2019). This approach that exploits laser scanning is referred to as a scan-toBIM process (Bosché et al., 2015). Appropriate 3D data for creating as-built BIM models can be produced by all types of laser scanning devises and techniques, including terrestrial, mobile and airborne methods (Badenko et al., 2019).

\subsection{Pre-Processing of Data and 3D Modelling}

Images or range data of the existing building is often used for 3D modelling (Stamos and Allen, 2000; Volk et al., 2014). First, this data, usually gathered by photogrammetric methods or laser scanning, needs to be processed (Murphy et al., 2017). The initial pre-processing phase often involves cleaning and removing incorrect points and point cloud registration (Murphy et al., 2017; Pətroucean et al., 2015; Pocobelli et al., 2018), whereas the following modelling phase contains meshing (Murphy et al., 2009) and texturing (Pocobelli et al., 2018). Even though a point cloud may be used independently, it is often used as a source of information for the creation of a 3D inventory model or a 3D surface model, and also for 2D drawings (Randall, 2011). Since the point clouds do not contain additional information about the registered objects, such as geometrical, topological, and semantic attributes, this information needs to be generated during the 3D modelling phase (López et al., 2018). Although the pre-processing of data is becoming increasingly automated, the 3D modelling phase is still rather laborious due to heavy manual work (Dore and Murphy, 2017; Omar and Nehdi, 2016). However, semi-automatic and automatic modelling approaches can also be utilised in this process (Hong et al., 2015; Liu, 2016; López et al., 2018; Macher et al., 2017). The traditional 3D CAD model contains only parametric and feature-based information, whereas BIM platforms enable having a vast amount of semantic information about building elements and their use and maintenance (Dore and Murphy, 2017; López et al., 2018; Pocobelli et al., 2018). Currently, there are various BIM software products, such as ArchiCAD, Revit and Tekla structures, available on the market for as-built BIM creation (Barazzetti, 2016; Logothetis et al., 2015).

In Finland, the collected information and measures referring to objects of an existing building are commonly called an inventory model and the term 'BIM' typically signifies the body of information over the entire lifespan of a certain building (RT 10-11067, 2012). An inventory model is not necessarily presented in 3D form. It may be, for example, formed as a collection of documents, and each document contains information of a certain room (RT 1011067, 2012).

\section{METHODS}

The primary purpose of this study was to investigate the barriers to laser scanning in building refurbishment projects in Finland. In order to better understand this theme, including project parties' viewpoints, qualitative semistructured interviews were conducted. A semi-structured interview as a method is based on a list of themes that are covered during the interview (Greener, 2008). Qualitative interviews were selected as they provide in-depth information about the experiences of individuals (DiCicco-Bloom and Crabtree, 2006); give a better understanding of situations; are appropriate for describing the processes; and help the researcher to understand how events are interpreted (Weiss, 1995). In addition, since previous research on the topic is limited, this method allowed the researcher to collect data flexibly and ask elaborate questions during the interview (Hirsjärvi et al., 2007).

Firstly, the selected themes considered acquiring measurement data of building refurbishment projects more broadly to examine the current situation in the field. Secondly, the focus was on the use of LS with the aim of 
extending the understanding of the barriers to and current challenges of LS and data processes in these projects. These selected themes were the following:

- Measurement data of building refurbishment projects

- Measurement processes of building refurbishment projects

- Use of LS in building refurbishment projects

The questions were formulated in advance, but the order of the questions varied between the interviews, as some questions were partly answered in previous topics. A list of the themes and questions was sent to the interviewees in advance.

Since the use of LS is still rather rare in building refurbishment projects in Finland, the appropriate persons to interview were identified by searching through related publications and projects in which LS had been used, contacting pioneering organisations in the use of LS in refurbishment projects, and contacting participants of and organisations involved in LS training organised in Finland between 2016 and 2017. To get a wider perspective of the studied themes, the respondents were chosen from different Finnish companies and organisations, and also the respondents' job titles and work assignments vary. Nine persons with experience of LS in building refurbishment projects were interviewed between autumn 2017 and early winter 2018. The titles and responsibilities of the interviewees are presented in Table 1.

Table 1. The interviewees' titles and responsibilities

\begin{tabular}{lll}
\hline Title & Job description \\
\hline architect & director of building information modelling team \\
\hline architect & responsible for construction contracting \\
\hline architect & specialised in building refurbishment \\
\hline architect & project director \\
\hline managing director & point cloud expert \\
\hline archaeologist & $\begin{array}{l}\text { consulting and coordination of building information } \\
\text { modelling }\end{array}$ \\
\hline modelling engineer, land surveyor & $\begin{array}{l}\text { responsible for the management of digital documentation of } \\
\text { buildings }\end{array}$ \\
\hline manager & $\begin{array}{l}\text { director of laser scanning team } \\
\text { manager of maintenance of parish buildings }\end{array}$ \\
\hline
\end{tabular}

The interviewees' experience of LS in building refurbishment varied greatly as some had been involved in only one project where LS was utilised, and some had used it regularly over a period of ten years. Thus, there was considerable variation in the respondents' knowledge of this technique and their skill in using it. The interviewees represented both the public and private sector, and also among the projects they had gathered their LS experience from, there were both public and private ones. These projects include refurbishments of historic buildings; parish buildings; residential buildings; and municipal buildings, including schools, hospitals, and offices. These projects also include geometrically demanding buildings and buildings of considerable cultural and historical significance. The duration of each interview was 45-100 minutes, and each interview was digitally recorded. The gathered data were analysed thematically.

\section{RESULTS}

Multiple challenges in the use of laser scanning and barriers to its implementation were identified in the interviews. These barriers were divided into three categories as follows:

- barriers related to challenges in the procurement of LS services

- barriers linked to the limitations of the LS technique

- barriers related to the limitations to the utilisation of the data in design work 


\subsection{Barriers Related to Procurement of Laser Scanning Services}

As expertise and tools are required in LS and the data process, they are typically purchased from a company. In a building refurbishment project, the simplest level of procurement is laser scanning of the building and a point cloud. This level is commonly used in projects, where the client's organisation or designer performs the further processing of the LS data. Other commonly used levels include procurement of the LS and data processing into 2D pictures or into an inventory model. Often, the company carrying out the LS task in a building does not process the data from a point cloud into further models. Instead, the company has a contract with another company that converts the LS data further into an inventory model or into 2D pictures.

The main challenge in the procurement of LS is the technical determination of the scanning. The principal designer is rarely involved in the project at the phase when LS is procured. Therefore, the technical specifications of the LS are, usually, determined by the client. As a consequence, the LS operation may be inappropriately specified, and the data may be incomplete or incorrect for the designer's software. Thus, the designer might not be able to use the data at all or the use of the data can be very inconvenient and time-consuming because of incompatible formats or technical details. Converting data into another format is possible but it is time-consuming, and some data might be lost in the process. The interviewees agreed that if the designer is not involved in the process of determining the contents of the LS, the client should know what type of as-built information, regarding, for example, data accuracy, can be utilised in certain design work. In addition, the client should build a vast knowledge of different data acquisition methods, including an understanding of the limits and the possibilities of each method.

In some refurbishment projects, the determination of the scope of the LS on the contract has been challenging. Into the content of the contract, it is often written that all visible surfaces will be scanned. However, the line between visible and non-visible surfaces is often ambiguous. For example, the roof and the attic are often included in the visible surfaces, but also sometimes in the non-visible. Furthermore, despite a clearly defined scope, the LS work has, occasionally, been sloppy, as recesses in rooms have been outside of the range of the laser, or attics, pipe ducts or lift shafts have been left out of the scan. According to the interviewees, the scope of the LS should be well defined in the conditions of contract in order to avoid ambiguity in the content.

Often, the client uses the publication series Common BIM requirements 2012, 'CBIMR', when purchasing LS in Finland. The CBIMR is a Finnish publication series that contains the basic principles, requirements, definitions and concepts that can be followed in BIM-based projects. For creating an inventory model or other as-built documentation, CBIMR instructs to laser scan all visible surfaces comprehensively by using a maximum noise error margin of $\pm 10 \mathrm{~mm}$ and a point density of less than $5 \mathrm{~mm}$ intervals (RT 10-11067, 2012). Often, the clients have used those levels of accuracy when purchasing LS. However, many interviewees emphasised that these accuracy levels of scanning are often inappropriate. For example, if all the visible surfaces of a large-sized building are scanned with $5 \mathrm{~mm}$ point density, the size of the files becomes so large that the use of the files might be inconvenient. A sparse accuracy level is appropriate, for example, in projects where only the surface of the structures will be repaired. In short, the major barriers related to the procurement of LS services are the following:

- the client does not have competence for technical determination; and

- the gathered data may be futile for design work.

\subsection{Barriers Linked to the limitations of the Laser Scanning Technique}

Mostly, LS data is utilised in the design work by processing the LS data into 2D pictures or into an inventory model. It is also utilised in building contracting, quantity surveying, visualisation of the existing building, and verification of the area of rooms for room leasing and sale purposes. Even though the interviewees considered LS to be useful in many projects, several challenges in its use and barriers to its implementation were identified. The key barriers and challenges are listed as follows:

- expensive to use in minor refurbishment projects and in projects where so accurate as-built data is not needed;

- challenges in data acquisition in a building when users are in residence;

- challenges when using LS outdoors during the summer and the winter; and

- challenges in collecting data from roofs and eaves. 
LS is perceived to be beneficial especially in major building refurbishment projects, in which accurate as-built data of multiple rooms or an entire building is needed. In addition, it is considered to be essential in the conservation of historical buildings, and useful in buildings with complicated geometric shapes and with a lot of technical equipment and structures not recorded in drawings. However, the interviewees considered the use of LS to be rather inappropriate and expensive in projects with only minor repairs. In those projects, the use of drawings and conventional measurement methods were perceived to be more practicable. In addition, LS is considered to be useless in refurbishment projects where accurate as-built data is not needed.

The interviewees considered LS difficult to carry out in an occupied building, as people in the view of the laser scanner cover the surfaces to be measured. Thus, the view of the scanner to the room is not solid. In addition, the interviewees have met various challenges when using LS outdoors. Vegetation and snow lining a building façade, as well as windy weather conditions have hindered the LS operation. Furthermore, this data, containing empty areas due to obstructions, is later laborious to process. As a consequence, the spring and the autumn were suggested to be the most suitable times for LS outdoors.

When acquiring data of a façade, a laser scanner is usually operated on the ground. However, eaves of the building disturb data acquisition, and thus, the roof and some sections of eaves are often left in a blind spot. Therefore, another measuring method, such as drone photogrammetry, is often needed in those places. Sometimes, data of the roof is collected by using a laser scanner on the roof, but the use of the device on a sloping surface is found to be dangerous and may lead to accidents.

Basically, LS can be operated in places where the scanner fits. For example, LS can be used successfully for data acquisition in false ceilings by pushing the scanner up through a hole in the false ceiling, whereupon the laser scanner scans the inner part of the false ceiling. However, interviewees considered data acquisition of these cramped places, such as ducts and canals, often to be challenging, as locations from where to operate the laser scanner in these structures are, typically, hard to find.

\subsection{Barriers Associated with Data Processing and Data Utilisation in Design work}

The interviewees expressed several barriers to LS implementation related to data processing and design work. The main barriers are presented as follows:

- time-consuming and laborious data processing and modelling

- errors in models

- limited opportunities to utilise the data in design work, as critical places are hidden during LS

- large files

- limited opportunities to use the data in certain software products

The process from a point cloud into an inventory model is perceived to be time-consuming and error-prone, and according to the interviewees, the modellers do not always have a clear understanding of the designer's requirements. Errors and wrong objects in the model cause extra work for designers and may delay the project. For example, if the modeller has interpreted a false ceiling as an intermediate floor, the areas of the structures are incorrect. Often, the models also contain several negligence errors, such as objects in wrong places or missing columns. Moreover, as the predefined libraries of BIM modelling are planned for new constructions, the irregular shapes of existing buildings are challenging to model.

Laser scanned data is not usually used during a design development phase, because the data is not yet available. As a result, many corrections must be made in early designs during later phases. Usually, the designer does not receive a complete model at the beginning of the design phase. Instead, at the beginning of the design phase, the designer receives a model with only load-bearing structures, and the model is then completed during the designing process.

Since building refurbishment projects often contain alterations in rooms and system replacements, as-built data from above suspended ceilings, under floors and inside walls is needed. However, despite the large amount of structural demolition that the projects typically encompass, the as-built data is collected before the demolition actions. Thus, the items hidden behind the walls and under the floors are not included in the acquired data. Even though LS can be repeated after the demolition actions to gather the critical measures, it is rarely used at this phase, since it is considered to be too laborious and time-consuming. 


\section{DISCUSSION}

The results of this study indicate that greater benefits of laser scanning are achieved in major refurbishment projects. However, the use of the technique is perceived to be inconvenient and expensive in projects with only minor refurbishment actions and in projects where so accurate as-built data is not needed. The results of this study indicate that the use of LS might be beneficial in the refurbishment projects of buildings that have already been renovated, since renovation actions are often poorly documented, and hence, the drawings of these buildings are inaccurate.

According to the interviewees, an inventory model is typically more time-consuming to produce by using laser scanned data than the drawings of the existing building. Often, drawings of buildings built since the late 1990s are rather extensive and accurate. Thus, LS is considered to be rather unnecessary when refurbishing a building that has proper documents and has been built in the past 20 years. Furthermore, this statement is supported by the aforementioned fact of greater benefits in larger refurbishments, since major refurbishments more often concern the older building stock than buildings less than 20 years old.

LS is, typically, procured before the designer is involved in the project. Hence, the acquired point cloud data is often rather inappropriate for the design, either in accuracy or in scope. However, the designer can, then, potentially use the data already in design development. Whereas, if LS is purchased after the designer has entered the project, the scope and details of the LS task can be determined in co-operation with the designer and measurers. Thus, the captured data benefits the designer as much as possible. However, the designer cannot then, usually, utilise the data in the design development phase, yet. As a result, many corrections to the early design must be made during later design phases.

These results indicate that a modification of the project preparation process is needed, as the designer's involvement during the early phase of the building refurbishment project appears to be vital. By involving the designer in the project preparation, the designer could assess the requirements concerning the as-built data of the existing building. In addition, the designer could contribute to the technical determination of LS, including describing the scope, content, levels of details, delivery formats, and accuracy of the data acquisition. By implementing LS at a very early phase of the project, the designer could use the data already in the design development, which may reduce overlapping work in later design phases. Consistent with previous research (Uotila et al., 2020b), also project uncertainty may be reduced by using accurate data already in the early project phase. Furthermore, this modification to the project preparation process could reduce the needs concerning a client's competence to purchase as-built data.

Many challenges that reduce the interest towards LS are met during and after the process from a point cloud into an inventory model. These challenges, such as the use of a wrong format or producing an inconvenient model for the designer, could be reduced by including the process from a point cloud into an inventory model in the designer's contract. However, the results of this study imply that designers rarely have the competence or the interest in making inventory models. Thus, the best utilisation of the model is often achieved when the designer and the inventory modeller co-operate already at the beginning of the modelling process. Hence, it is important that the designer is involved in the project before the modelling phase starts.

As the project preparation phase requires modification, the phase of LS implementation can also be improved. Since it has been claimed that occupied buildings are difficult to scan, it might be advisable to plan the LS implementation schedule together with the building users. Thus, the LS can be operated in a systematic order without interruption and users in the rooms.

The results of this study imply that uncertainty related to the advantages of LS may restrain the use of this technique. Defects in the measurement plan may significantly reduce the usefulness of the data. For example, blind spots in the laser range significantly hinder as-built creation and may impede the designer's work and increase uncertainty related to the design. Therefore, great competence is needed when purchasing LS services. In addition, designers' reports of multiple faults in the models and LS producers' carelessness in their work might reduce clients' interest towards LS. Furthermore, despite the multiple advantages that the LS technique provides, other data acquisition techniques, such as a tacheometry, a drone or a laser range finder, are usually needed to be used in parallel with a laser scanner in refurbishment projects, as not all of the required measurements and information can be gathered with just a laser scanner. 
The interviews revealed multiple restrictions and practical challenges concerning technical issues of LS in refurbishment projects. These features include the determination of the content and accuracy of LS, the use of different formats as well as shortages in modellers' understanding of building structures and designers' needs. Also, a lack of computing power when handling large point-cloud files was considered to be a challenge, corresponding to the findings of Shanbari et al. (2016). Coinciding with the studies of Cheng et al. (2015) and Tang et al. (2010), the as-built modelling of an existing building was perceived to be a laborious and timeconsuming task, because of these technical challenges, and due to the as-built BIM's lack of pre-defined parametric objects suitable for existing buildings. These difficulties in creating an as-built model of existing or historical buildings have also been reported in other studies (Dore and Murphy, 2017). However, this problem could be, at least to some extent, overcome by using databases of elements of historic buildings, which have been created, for example, by Fai and Rafeiro (2014) and Murphy et al. (2013). These aforementioned technical challenges and the laboriousness in processing potentially reduce the interest towards the use of this technique in building refurbishment projects.

The interviewees' competence in utilising LS in building refurbishment projects varied significantly, as well as their understanding of the benefits and possibilities of the technique. This indicates that understanding of the benefits and limitations of the LS technique in building refurbishments might still be rather deficient. This limited understanding may become a barrier to implementing LS in building refurbishments. In particular, if clients and building owners are not aware of the potential of LS, they are not willing to pay for these services. Thus, increased understanding of this technique is needed especially at the beginning of projects. Broader knowledge of LS could increase the utilisation of the technique, and the method could be used in more useful ways.

The study shows that the full potential of laser scanning has not been utilised in building refurbishment projects. In Finland, as-built BIMs are not yet commonly used in refurbishment projects due to the laborious work of 3D modelling. However, since the modelling technique still evolves and more automation is adopted, the popularity of BIM implementation in existing buildings might increase. Hence, accurate spatial data will have particular importance, which may result in an increase in the use of laser scanning. Furthermore, more advanced laser scanning techniques, including compact devices, may also increase the popularity of this technique over the coming years.

\section{CONCLUSIONS}

The barriers to laser scanning implementation in building refurbishment projects were studied by conducting nine qualitative interviews. The study shows that the main barriers to the implementation are associated with clients' lack of competence to procure LS services. They are also linked to the limitations of the LS technique in building refurbishment; and to the limitations and challenges in utilising the captured data in design work. In addition, the rather varied quality of purchased inventory models, as well as laborious processes, may reduce interest in the technique.

Since the process from a point cloud into an inventory model is laborious, time-consuming and error-prone, the LS technique is perceived as being a rather unsuitable tool for projects with minor refurbishment work. Hence, this study indicates that a larger extent of refurbishment actions is connected to greater benefits of the technique. In addition, as the drawings of buildings built since the late 1990s are, typically, relatively appropriate and accurate, it is considered that an inventory model is less time-consuming and laborious to produce by using the drawings instead of a point cloud. Therefore, the benefits of the technique are fewer when refurbishing buildings built in the past 20 years compared to the benefits gained in the refurbishments of older buildings. The study also shows, that understanding of LS is still rather limited and insufficient among the stakeholders of building refurbishment projects, which potentially reduces the utilisation of the technique in these projects.

As this study was conducted through interviews, the results are majorly based on the respondents' perceptions and experiences. In order to identify the challenges for the use of laser scanning in building refurbishment projects in Finland, and to provide more information on how these obstacles can be overcome, the authors suggest further research. For example, case studies of building refurbishment projects, in which laser scanning is applied in data acquisition, data modelling and documentation, could provide even more detailed information of this theme. 
Despite the limitations of this research, this study can be beneficial for building owners and practitioners, as the findings may be utilised in the procurement of LS and as-built models in building refurbishments. In addition, the suggestions that the study provides might be useful in improving the early phase of a refurbishment project.

\section{REFERENCES}

Abdul Shukor, S.A., Wong, R., Rushforth, E., Basah, S.N. and Zakaria, A. (2015), “3D terrestrial laser scanner for managing existing building”, Jurnal Teknologi, available at: https://doi.org/10.11113/jt.v76.5895.

Aicardi, I., Chiabrando, F., Maria Lingua, A. and Noardo, F. (2018), "Recent trends in cultural heritage 3D survey: The photogrammetric computer vision approach", Journal of Cultural Heritage, available at: https://doi.org/10.1016/j.culher.2017.11.006.

Akinci, B., Boukamp, F., Gordon, C., Huber, D., Lyons, C. and Park, K. (2006), “A formalism for utilization of sensor systems and integrated project models for active construction quality control”, Automation in Construction, Vol. 15 No. 2, pp. 124-138.

Ali, A.S., Rahmat, I. and Hassan, H. (2008), "Involvement of key design participants in refurbishment design process", Facilities, available at: https://doi.org/10.1108/02632770810885742.

Allegra, V., Di Paola, F., Lo Brutto, M. and Vinci, C. (2020), "SCAN-TO-BIM for the MANAGEMENT of HERITAGE BUILDINGS: The CASE STUDY of the CASTLE of MAREDOLCE (PALERMO, ITALY)", International Archives of the Photogrammetry, Remote Sensing and Spatial Information Sciences - ISPRS Archives, available at :https://doi.org/10.5194/isprs-archives-XLIII-B2-2020-1355-2020.

Alomari, K., Gambatese, J. and Olsen, M.J. (2016), "Role of BIM and 3D Laser Scanning on Job sites from the Perspective of Construction Project Management Personnel”, Construction Research Congress 2016, available at: https://doi.org/10.1061/9780784479827.252.

Altman, S., Xiao, W. and Grayson, B. (2017), "Evaluation of Low-Cost Terrestial Photogrammetry fo 3D Reconstruction of Complex Buildings", ISPRS Annals of the Photogrammetry, Remote Sensing and Spatial Information Sciences, available at: https://doi.org/10.5194/isprs-annals-IV-2-W4-199-2017.

Amano, K., Lou, E.C.W. and Edwards, R. (2019), "Integration of point cloud data and hyperspectral imaging as a data gathering methodology for refurbishment projects using building information modelling (BIM)", Journal of Facilities Management, available at: https://doi.org/10.1108/JFM-11-2017-0064.

Arain, F.M. (2005), "Potential barriers in management of refurbishment projects", Journal of Independent Studies and Research, Vol. 3 No. 1, pp. 22-31.

Badenko, V., Fedotov, A., Zotov, D., Lytkin, S., Volgin, D., Garg, R.D. and Min, L. (2019), "Scan-to-bim methodology adapted for different application", International Archives of the Photogrammetry, Remote Sensing and Spatial Information Sciences - ISPRS Archives, available at: https://doi.org/10.5194/isprs-archives-XLII-5-W2-1-2019.

Barazzetti, L. (2016), "Parametric as-built model generation of complex shapes from point clouds", Advanced Engineering Informatics, available at: https://doi.org/10.1016/j.aei.2016.03.005.

Bassier, M., Klein, R., Van Genechten, B. and Vergauwen, M. (2018), "IFC Wall reconstruction from unstructured point clouds", Annals of the Photogrammetry Remote Sensing and Spatial Information Sciences, Copernicus GmbH, Vol. 4 No. 2, pp. 33-39.

Becker, R., Lublasser, E., Martens, J., Wollenberg, R., Zhang, H., Brell-Cokcan, S. and Blankenbach, J. (2019), "Enabling BIM for property management of existing buildings based on automated As-IS capturing", Proceedings of the 36th International Symposium on Automation and Robotics in Construction, ISARC 2019, available at: https://doi.org/10.22260/isarc2019/0028.

Bosché, F., Ahmed, M., Turkan, Y., Haas, C.T. and Haas, R. (2015), "The value of integrating Scan-to-BIM and Scanvs-BIM techniques for construction monitoring using laser scanning and BIM: The case of cylindrical MEP components", Automation in Construction, available at: https://doi.org/10.1016/j.autcon.2014.05.014.

Brilakis, I., Lourakis, M., Sacks, R., Savarese, S., Christodoulou, S., Teizer, J. and Makhmalbaf, A. (2010), “Toward automated generation of parametric BIMs based on hybrid video and laser scanning data", Advanced Engineering Informatics, Vol. 24 No. 4, pp. 456-465.

Capone, M. and Lanzara, E. (2019), "SCAN-TO-BIM vs 3D IDEAL MODEL HBIM: PARAMETRIC TOOLS TO 
STUDY DOMES GEOMETRY.”, International Archives of the Photogrammetry, Remote Sensing $\backslash \&$ Spatial Information Sciences.

Cepurnaite, J., Ustinovicius, L. and Vaisnoras, M. (2017), "Modernization with BIM technology through scanning building information”, Procedia Engineering, Vol. 208, pp. 8-13.

Chen, C., Tang, L., Hancock, C.M. and Zhang, P. (2019), "Development of low-cost mobile laser scanning for 3D construction indoor mapping by using inertial measurement unit, ultra-wide band and 2D laser scanner", Engineering, Construction and Architectural Management, available at: https://doi.org/10.1108/ECAM-06-20180242 .

Cheng, H.M., Yang, W. Bin and Yen, Y.N. (2015), "BIM applied in historical building documentation and refurbishing", International Archives of the Photogrammetry, Remote Sensing and Spatial Information Sciences - ISPRS Archives, available at: https://doi.org/10.5194/isprsarchives-XL-5-W7-85-2015.

Chua, D.K.H., Tyagi, A., Ling, S. and Bok, S.H. (2003), "Process-Parameter-Interface Model for Design Management”, Journal of Construction Engineering and Management, Vol. 129 No. 6, pp. 653-663.

DiCicco-Bloom, B. and Crabtree, B.F. (2006), “The qualitative research interview”, Medical Education, available at: https://doi.org/10.1111/j.1365-2929.2006.02418.x.

Dobelis, M., Kalinka, M. and Borodinecs, A. (2016), "The Capture of BIM Compatible 3D Building Model from Laser Scanner Data", The 17th International Conference on Geometry and Graphics, Vol. China, Bei, pp. 4-8.

Dore, C. and Murphy, M. (2012), "Integration of Historic Building Information Modeling (HBIM) and 3D GIS for recording and managing cultural heritage sites", 2012 18th International Conference on Virtual Systems and Multimedia, pp. 369-376.

Dore, C. and Murphy, M. (2017), "CURRENT STATE OF THE ART HISTORIC BUILDING INFORMATION MODELLING”, International Archives of the Photogrammetry, Remote Sensing \& Spatial Information Sciences, Vol. 42.

Ebolese, D., Dardanelli, G., Lo Brutto, M. and Sciortino, R. (2018), “3D survey in complex archaeological environments: An approach by terrestrial laser scanning", International Archives of the Photogrammetry, Remote Sensing and Spatial Information Sciences - ISPRS Archives, available at: https://doi.org/10.5194/isprs-archives-XLII-2-3252018.

Fai, S. and Rafeiro, J. (2014), "Establishing an appropriate level of detail (LOD) for a building information model (BIM) - West Block, Parliament Hill, Ottawa, Canada”, ISPRS Annals of the Photogrammetry, Remote Sensing and Spatial Information Sciences, available at: https://doi.org/10.5194/isprsannals-II-5-123-2014.

Fassi, F., Fregonese, L., Ackermann, S. and De Troia, V. (2013), "Comparison between laser scanning and automated 3D modelling techniques to reconstruct complex and extensive cultural heritage areas", ISPRS - International Archives of the Photogrammetry, Remote Sensing and Spatial Information Sciences, available at: https://doi.org/10.5194/isprsarchives-xl-5-w1-73-2013.

Gimenez, L., Hippolyte, J.L., Robert, S., Suard, F. and Zreik, K. (2015), "Review: Reconstruction of 3D building information models from 2D scanned plans”, Journal of Building Engineering.

Göçer, Ö., Hua, Y. and Göçer, K. (2016), “A BIM-GIS integrated pre-retrofit model for building data mapping”, Building Simulation, Vol. 9 No. 5, pp. 513-527.

Golparvar-Fard, M., Bohn, J., Teizer, J., Savarese, S. and Peña-Mora, F. (2011), "Evaluation of image-based modeling and laser scanning accuracy for emerging automated performance monitoring techniques", Automation in Construction, Vol. 20 No. 8, pp. 1143-1155.

Greener, S. (2008), Business Research Methods, BookBoon.

Gruen, A. (2012), "Development and Status of Image Matching in Photogrammetry", Photogrammetric Record, available at: https://doi.org/10.1111/j.1477-9730.2011.00671.x.

Han, S. et al. (2012), “Automated and efficient method for extraction of tunnel cross sections using terrestrial laser scanned data", Journal of Computing in Civil Engineering, No. 27.3., pp. 274-281.

Hichri, N., Stefani, C., De Luca, L. and Veron, P. (2013), "Review of the « as-built bim » approaches", International Archives of the Photogrammetry, Remote Sensing and Spatial Information Sciences - ISPRS Archives. 
Hirsjärvi, S., Remes, P. and Sajavaara, P. (2007), “Tutki ja kirjoita. 13., osin uudistettu painos”, Helsinki: Tammi, Vol. 23, pp. 190-194.

Historic England. (2018), “3D Laser Scanning for Heritage: Advice and Guidance on the Use of Laser Scanning in Archaeology and Architecture", Historic England.

Hong, S., Jung, J., Kim, S., Cho, H., Lee, J. and Heo, J. (2015), "Semi-automated approach to indoor mapping for 3D as-built building information modeling", Computers, Environment and Urban Systems, available at: https://doi.org/10.1016/j.compenvurbsys.2015.01.005.

Khodeir, L.M., Aly, D. and Tarek, S. (2016), "Integrating HBIM (Heritage Building Information Modeling) Tools in the Application of Sustainable Retrofitting of Heritage Buildings in Egypt", Procedia Environmental Sciences, available at: https://doi.org/10.1016/j.proenv.2016.04.024.

Kukko, A. and Kaartinen, H. (2019), “Multiplatform mobile laser scanning”, Laser Scanning: An Emerging Technology in Structural Engineering, CRC Press, Vol. 14, p. 19.

Lachat, E., Landes, T. and Grussenmeyer, P. (2017), "Investigation of a combined surveying and scanning device: the trimble SX10 scanning total station”, Sensors, Multidisciplinary Digital Publishing Institute, Vol. 17 No. 4, p. 730.

Le, A.T.H., Park, K.S., Domingo, N., Rasheed, E. and Mithraratne, N. (2018), "Sustainable refurbishment for school buildings: a literature review", International Journal of Building Pathology and Adaptation.

Lee, J., Hong, S., Cho, H., Park, I., Cho, H. and Sohn, H.-G. (2015), “Accuracy Comparison Between Image-based 3D Reconstruction Technique and Terrestrial LiDAR for As-built BIM of Outdoor Structures", Journal of the Korean Society of Surveying, Geodesy, Photogrammetry and Cartography, available at: https://doi.org/10.7848/ksgpc.2015.33.6.557.

Lehtola, V. V., Kaartinen, H., Nüchter, A., Kaijaluoto, R., Kukko, A., Litkey, P., Honkavaara, E., et al. (2017), "Comparison of the selected state-of-the-art 3D indoor scanning and point cloud generation methods", Remote Sensing, Vol. 9 No. 8, available at: https://doi.org/10.3390/rs9080796.

Liu, Y. (2016), "Robust segmentation of raw point clouds into consistent surfaces”, Sci. China Technol. Sci., Vol. 59, pp. 1156-1166.

Liu, Y. and Kang, J. (2014), “Application of Photogrammetry: 3D Modeling of a Historic Building”, Construction Research Congress 2014: Construction in a Global Network.

Logothetis, S., Delinasiou, A. and Stylianidis, E. (2015), "Building information modelling for cultural heritage: A review", ISPRS Annals of the Photogrammetry, Remote Sensing and Spatial Information Sciences, available at: https://doi.org/10.5194/isprsannals-II-5-W3-177-2015.

López, F.J., Lerones, P.M., Llamas, J. and Gómez-García-Bermejo, J. Zalama, E. (2018), “A Review of Heritage Building Information Modeling (H-BIM)”, Multimodal Technologies and Interaction, Vol. 2 No. 2.

Love, P.E.D. and Edwards, D.J. (2004), "Determinants of rework in building construction projects", Engineering, Construction and Architectural Management, available at: https://doi.org/10.1108/09699980410547612.

Macher, H., Landes, T. and Grussenmeyer, P. (2017), "From Point Clouds to Building Information Models: 3D SemiAutomatic Reconstruction of Indoors of Existing Buildings", Applied Sciences, available at: https://doi.org/10.3390/app7101030.

McKim, R., Hegazy, T. and Attalla, M. (2000), "Project performance control in reconstruction projects", Journal of Construction Engineering and Management, Vol. 126 No. 2, pp. 137-141.

Mellado, F., Wong, P.F., Amano, K., Johnson, C. and Lou, E.C.W. (2020), "Digitisation of existing buildings to support building assessment schemes: Viability of automated sustainability-led design scan-to-BIM process", Architectural Engineering and Design Management, Taylor $\ \&$ Francis, Vol. 16 No. 2, pp. 84-99.

Murphy, M., Corns, A., Cahill, J., Eliashvili, K., Chenau, A., Pybus, C., Shaw, R., et al. (2017), "Developing historic building information modelling guidelines and procedures for architectural heritage in Ireland", International Archives of the Photogrammetry, Remote Sensing and Spatial Information Sciences - ISPRS Archives, available at: https://doi.org/10.5194/isprs-archives-XLII-2-W5-539-2017.

Murphy, M., Mcgovern, E. and Pavia, S. (2009), "Historic building information modelling (HBIM)”, Structural Survey, 
available at: https://doi.org/10.1108/02630800910985108.

Murphy, M., McGovern, E. and Pavia, S. (2013), "Historic Building Information Modelling - Adding intelligence to laser and image based surveys of European classical architecture”, ISPRS Journal of Photogrammetry and Remote Sensing, available at: https://doi.org/10.1016/j.isprsjprs.2012.11.006.

Murtiyoso, A. and Grussenmeyer, P. (2018), "Comparison and assessment of 3D registration and georeferencing approaches of point clouds in the case of exterior and interior heritage building recording", ISPRS TC II Mid-Term Symposium" Towards Photogrammetry 2020", Vol. 42, pp. 745-751.

Naaranoja, M. and Uden, L. (2007), "Major problems in renovation projects in Finland", Building and Environment, Vol. 42 No. 2, pp. 852-859.

Nguyen, C.H.P. and Choi, Y. (2018), "Comparison of point cloud data and 3D CAD data for on-site dimensional inspection of industrial plant piping systems", Automation in Construction, available at: https://doi.org/10.1016/j.autcon.2018.03.008.

Noori, A., Saruwono, M., Adnan, H. and Rahmat, I. (2016), "Conflict, Complexity, and Uncertainty in Building Refurbishment Projects”, InCIEC 2015, available at: https://doi.org/10.1007/978-981-10-0155-0_24.

Oloke, D. (2017), "Improving information quality and communication effectiveness in health and safety management of refurbishment projects - A case study approach", Joint CIB W099 \& TG59 International Safety, Health, and People in Construction Conference, p. 467.

Omar, T. and Nehdi, M.L. (2016), "Data acquisition technologies for construction progress tracking”, Automation in Construction, available at: https://doi.org/10.1016/j.autcon.2016.06.016.

Otero, R., Lagüela, S., Garrido, I. and Arias, P. (2020), "Mobile indoor mapping technologies: A review", Automation in Construction, Vol. 120, available at: https://doi.org/10.1016/j.autcon.2020.103399.

Pətrəucean, V., Armeni, I., Nahangi, M., Yeung, J., Brilakis, I. and Haas, C. (2015), "State of research in automatic asbuilt modelling", Advanced Engineering Informatics, available at: https://doi.org/10.1016/j.aei.2015.01.001.

Piselli, C., Romanelli, J., Di Grazia, M., Gavagni, A., Moretti, E., Nicolini, A., Cotana, F., et al. (2020), “An integrated HBIM simulation approach for energy retrofit of historical buildings implemented in a case study of a medieval fortress in Italy", Energies, available at: https://doi.org/10.3390/en13102601.

Pocobelli, D.P., Boehm, J., Bryan, P., Still, J. and Grau-Bové, J. (2018), "BIM for heritage science: a review”, Heritage Science, available at: https://doi.org/10.1186/s40494-018-0191-4.

Previtali, M., Banfi, F. and Brumana, R. (2019), "Handheld 3D Mobile Scanner (SLAM): Data Simulation and Acquisition for BIM Modelling”, International Workshop on R3 in Geomatics: Research, Results and Review, pp. 256-266.

Rahmat, I. and Ali, A.S. (2010), “The involvement of the key participants in the production of project plans and the planning performance of refurbishment projects”, Journal of Building Appraisal, Springer, Vol. 5 No. 3, pp. 273288.

Rocha, Mateus, Fernández and Ferreira. (2020), “A Scan-to-BIM Methodology Applied to Heritage Buildings", Heritage, available at: https://doi.org/10.3390/heritage3010004.

RT 10-11067. (2012), Common BIM Requirements 2012 Series 2, available at: http://rt.rakennustieto.fi/resource/juha/content/10219.

Sanhudo, L., Ramos, N.M.M., Martins, J.P., Almeida, R.M.S.F., Barreira, E., Simões, M.L. and Cardoso, V. (2020), “A framework for in-situ geometric data acquisition using laser scanning for BIM modelling”, Journal of Building Engineering, Vol. 28, available at: https://doi.org/10.1016/j.jobe.2019.101073.

Sanhudo, L., Ramos, N.M.M., Poças Martins, J., Almeida, R.M.S.F., Barreira, E., Simões, M.L. and Cardoso, V. (2018), "Building information modeling for energy retrofitting - A review", Renewable and Sustainable Energy Reviews, Vol. 89, pp. 249-260.

Sepasgozar, S.M.E., Lim, S., Shirowzhan, S., Kim, Y.M. and Nadoushani, Z.M. (2015), "Utilisation of a New Terrestrial Scanner for Reconstruction of As-built Models: A Comparative Study", ISARC. Proceedings of the International Symposium on Automation and Robotics in Construction.

Shanbari, H.A., Blinn, N.M. and Issa, R.R. (2016), "Laser scanning technology and BIM in construction management 
education”, Journal of Information Technology in Construction (ITcon), Vol. 21 No. 14, pp. 204-217.

Stamos, I. and Allen, P.K. (2000), "3-D model construction using range and image data", Proceedings of the IEEE Computer Society Conference on Computer Vision and Pattern Recognition, available at: https://doi.org/10.1109/cvpr.2000.855865.

Suchocki, C. (2020), "Comparison of time-of-flight and phase-shift TLS intensity data for the diagnostics measurements of buildings”, Materials, available at: https://doi.org/10.3390/ma13020353.

Sun, Z. and Cao, Y.K. (2015), "Data processing workflows from low-cost digital survey to various applications: Three case studies of Chinese historic architecture", International Archives of the Photogrammetry, Remote Sensing and Spatial Information Sciences - ISPRS Archives, available at: https://doi.org/10.5194/isprsarchives-XL-5-W7-4092015.

Tang, P., Anil, E.B., Akinci, B. and Huber, D. (2011), "Efficient and Effective Quality Assessment of As-Is Building Information Models and 3D Laser-Scanned Data", Computing in Civil Engineering (2011), pp. 486-493.

Tang, P., Huber, D., Akinci, B., Lipman, R. and Lytle, A. (2010), “Automatic reconstruction of as-built building information models from laser-scanned point clouds: A review of related techniques", Automation in Construction, Vol. 19 No. 7, pp. 829-843.

Tkáč, M., Mesároš, P. and Mandičák, T. (2018), “Terrestrial laser scanning--effective technology for creating building information models", Pollack Periodica, Akadémiai Kiadó, Vol. 13 No. 3, pp. 61-72.

Ulvi, A. (2021), "Documentation, Three-Dimensional (3D) Modelling and visualization of cultural heritage by using Unmanned Aerial Vehicle (UAV) photogrammetry and terrestrial laser scanners", International Journal of Remote Sensing, Taylor I\& Francis, Vol. 42 No. 6, pp. 1994-2021.

Uotila, U., Saari, A. and Junnonen, J.-M. (2020a), "Decision-making when organising facilities for a school: a participatory action research approach”, Facilities, Emerald Publishing Limited.

Uotila, U., Saari, A. and Junnonen, J.M. (2020b), "Uncertainty in the early phase of a municipal building refurbishment project-A case study in Finland”, Buildings, available at: https://doi.org/10.3390/BUILDINGS10080137.

Ustinovichius, L., Popov, V., Cepurnaite, J., Vilutienè, T. and Samofalov, M. Miedziałowski, C. (2018), "BIM-based process management model for building design and refurbishment", Archives of Civil and Mechanical Engineering, Vol. 18 No. 4, pp. 668-678.

Volk, R., Stengel, J. and Schultmann, F. (2014), "Building Information Modeling (BIM) for existing buildings Literature review and future needs", Automation in Construction, Vol. 38, pp. 109-127.

Wang, C., Cho, Y.K. and Kim, C. (2015), “Automatic BIM component extraction from point clouds of existing buildings for sustainability applications", Automation in Construction, available at: https://doi.org/10.1016/j.autcon.2015.04.001.

Wang, J., Sun, W., Shou, W., Wang, X., Wu, C., Chong, H.Y., Liu, Y., et al. (2015), "Integrating BIM and LiDAR for Real-Time Construction Quality Control”, Journal of Intelligent and Robotic Systems: Theory and Applications, available at: https://doi.org/10.1007/s10846-014-0116-8.

Weiss, R.S. (1995), Learning from Strangers: The Art and Method of Qualitative Interview Studies, Simon and Schuster.

Xiong, X., Adan, A., Akinci, B. and Huber, D. (2013), “Automatic creation of semantically rich 3D building models from laser scanner data", Automation in Construction, Vol. 31, pp. 325-337.

Yang, X., Grussenmeyer, P., Koehl, M., Macher, H., Murtiyoso, A. and Landes, T. (2020), "Review of built heritage modelling: Integration of HBIM and other information techniques", Journal of Cultural Heritage, Elsevier.

Zolkafli, U.K., Zakaria, N., Yahya, Z., Ali, A.S., Akashah, F.W., Othman, M. and Hock, Y.K. (2012), "Risks in Conservation Projects", Journal of Design+ Built, Vol. 5 No. 1. 